\section{Role of Circulating Somatostatin in Regulation of Gastric Acid Secretion, Gastrin Release, and Islet Cell Function Studies in Healthy Subjects
and Duodenal Ulcer Patients}

Thomas J. Colturi, Roger H. Unger, and Mark Feldman Department of Internal Medicine, Dallas Veterans Administration Medical Center and University of Texas Health Science Center, Dallas, Texas 75235

N

to the same extent in ulcer patients and controls. These studies suggest that duodenal ulcer patients release normal amounts of somatostatin into the circulation and that target cells controlling acid secretion and gastrin release are normally sensitive to somatostatin in these patients.

\section{Introduction}

Somatostatin is a peptide that has potent inhibitory actions on several target tissues (1). Because large amounts of somatostatin are present in the stomach and endocrine pancreas, it is possible that somatostatin normally regulates gastric and islet function. Possible modes of action of endogenous somatostatin on target cells within the stomach and islets are endocrine (via the systemic circulation), neurocrine (from somatostatin-containing nerves), and/or paracrine (via local diffusion) $(1,2)$.

Sensitive radioimmunoassays have documented increases in circulating somatostatin-like immunoreactivity (SLI) ${ }^{1}$ after meals in humans (3-8). Although high intravenous doses of somatostatin can inhibit gastric acid secretion and gastrin release (912), it is unknown whether the amount of somatostatin released into the circulation after a meal is of sufficient magnitude to affect gastric acid secretion or gastrin release. Therefore, studies were designed to determine whether enough somatostatin is released into the circulation after a meal to reduce gastric acid secretion or plasma gastrin concentrations. In addition, the effect of somatostatin on the pancreatic islets, another potential target of circulating somatostatin, was assessed by simultaneous measurements of plasma insulin and glucagon concentrations.

Patients with duodenal ulcer (DU) often demonstrate gastric acid hypersecretion and hypergastrinemia (13). Two studies have suggested that these patients may have reduced amounts of somatostatin in the gastric antrum $(14,15)$. If somatostatin normally plays a physiologic role in suppressing gastric acid

1. Abbreviations used in this paper: BAO, basal acid output; DU, duodenal ulcer; S-14, somatostatin-14; S-28, somatostatin-28; SLI, somatostatinlike immunoreactivity. 
secretion and gastrin release, somatostatin deficiency could contribute to acid hypersecretion and hypergastrinemia in some DU patients. It is also possible that insensitivity to inhibitory effects of somatostatin on the stomach could be present in some DU patients. Thus, another purpose of the present study was to compare in DU patients and normal subjects $(a)$ basal and food-stimulated circulating SLI; and $(b)$ inhibitory effects of exogenous somatostatin on gastric acid secretion and gastrin release.

\section{Methods}

Subjects and patients. 23 fasting healthy subjects ( 12 male) with no history of gastrointestinal or endocrine disorder were studied; their mean age was $31 \mathrm{yr}$ (range 20-52). Their weights averaged $66.3 \mathrm{~kg}$ (range 47.6-81.7 kg). Mean ( \pm SEM) basal acid output (BAO) and peak acid output in response to $6 \mu \mathrm{g} / \mathrm{kg}$ pentagastrin were $2.7 \pm 0.5$ and $29.9 \pm 1.6$ $\mathrm{mmol} / \mathrm{h}$, respectively. 10 fasting patients $(9$ male) with chronic DU were also studied. Their mean age was $49 \mathrm{yr}$ (range 21-60). Their weights averaged $79.8 \mathrm{~kg}$ (range $63.5-89.8 \mathrm{~kg}$ ). BAO and peak acid output averaged $8.5 \pm 2.6$ and $42.2 \pm 3.6 \mathrm{mmol} / \mathrm{h}$, respectively $(P<0.01$ vs. healthy subjects). No subject or patient was taking any medication and all gave written, informed consent. Studies were approved by a Human Research Review Committee.

Meals. Two different meals were used in these studies. One consisted of $227 \mathrm{~g}$ sirloin steak, $150 \mathrm{~g}$ french-fried potatoes, $28 \mathrm{~g}$ bread with $5 \mathrm{~g}$ butter, $8 \mathrm{oz}$. milk and an ice cream sandwich. This steak meal contained $83 \mathrm{~g}$ protein, $105 \mathrm{~g}$ carbohydrate, and $75 \mathrm{~g}$ fat $(1,440 \mathrm{cal})$. A second meal consisted of $143 \mathrm{~g}$ ground, lean, cooked hamburger, $28 \mathrm{~g}$ bread with $5 \mathrm{~g}$ butter, and $8 \mathrm{oz}$. water ( $546 \mathrm{cal}$ with $39 \mathrm{~g}$ protein, $30 \mathrm{~g}$ carbohydrate, and $30 \mathrm{~g}$ fat). As will be described in Results, the hamburger meal was either eaten intact or homogenized in a blender and infused into the stomach. The homogenized meal was diluted to $600 \mathrm{ml}$ with distilled water, adjusted to $\mathrm{pH} 5.5$ with $0.1 \mathrm{~N} \mathrm{HCl}$, and then infused by gravity into the stomach through a nasogastric tube (AN 10, Anderson Products, Inc., Oyster Bay, NY)

Somatostatin. Plasma SLI was measured as previously described (16) by radioimmunoassay with antibody $80 \mathrm{C}$ at a dilution of $1: 80,000$. This antibody appears to be directed against the central portion of somatostatin because immunoreactivity is completely lost when the L-tryptophan on the 8-position of somatostatin-14 (S-14) is replaced with D-tryptophan. On the other hand, immunoreactivity is maintained when the phenylalanine on the 11-position is replaced by tyrosine (Tyr) or when des-Ala ${ }^{1}$ S-14 or des-Ala ${ }^{1}-\mathrm{Gly}^{2}$ S-14 are used instead of native S-14. Therefore, ${ }^{125}$ I-labeled Tyr-11 S-14 was used as the tracer in these experiments (16). Half-maximal displacement of tracer occurred at an S-14 concentration of $20 \mathrm{pg} / \mathrm{ml}$ and a somatostatin- 28 (S-28) concentration of $120 \mathrm{pg} / \mathrm{ml}$. Thus, antibody $80 \mathrm{C}$ detected S-14 more readily than S- 28 by approximately threefold on a molar basis. The sensitivity of this assay (i.e., the minimal change in SLI concentration detectable with $95 \%$ confidence) is $5 \mathrm{pg} / \mathrm{ml}$. Intraassay variation was $6.1 \%$ and interassay variation $13.9 \%$.

Synthetic human S-14 for intravenous infusion was kindly provided by Clin-Midy, Montpellier, France (lot no. RLJ07) and was tested for use in human subjects at the Salk Institute, La Jolla, CA. Either S-14 or $0.15 \mathrm{M} \mathrm{NaCl}$ as a control was infused intravenously through an indwelling venous catheter in one arm (Imed infusion pump, Imed Corp., San Diego, CA). S-14 and control infusions contained $1 \%$ human serum albumin in order to prevent binding of peptide to plastic tubing.
S-14 and control studies were done on separate days in random order. $\mathrm{S}-14$ doses of $1,2.5,5,10,50$, and $100 \mu \mathrm{g} / \mathrm{h}$ were evaluated (see Results). Blood samples were obtained from a similar catheter in the opposite arm.

Gastric acid secretion. The effect of somatostatin on basal gastric acid output was measured by aspiration by using standard methods described previously (17). Hydrogen ion concentration was measured by $\mathrm{pH}$ electrode (18). Food-stimulated gastric acid secretion in response to the homogenized hamburger meal was measured by in vivo intragastric titration to pH 5.5 with $0.3 \mathrm{~N}$ sodium bicarbonate (19).

Gastrin, insulin, and glucagon. Coded plasma samples were assayed for gastrin, insulin, and glucagon concentrations by using previously described methods (20-22).

Statistical analysis. Statistical significance of differences between mean values was determined with $t$ test for paired values or groups. $P$ values of $<0.05$ were considered significant. During somatostatin infusion studies, blood hormone concentrations at 30 and $45 \mathrm{~min}$ of each infusion period were averaged and the mean value for each S-14 infusion period was compared with that during the corresponding $\mathrm{NaCl}$ infusion period.

\section{Results}

Basal plasma SLI. Basal SLI ranged from 3 to $11 \mathrm{pg} / \mathrm{ml}$ in 23 normal subjects and averaged $7.4 \pm 0.4 \mathrm{pg} / \mathrm{ml}$. In the $10 \mathrm{DU}$ patients, basal SLI ranged from 4 to $15 \mathrm{pg} / \mathrm{ml}$ and averaged $8.7 \pm 1.2 \mathrm{pg} / \mathrm{ml}(P>0.05$ vs. healthy subjects).

Plasma SLI response to eaten meals. In response to the steak meal, plasma SLI increased above basal concentrations in all normal subjects studied. Mean SLI increased from $6.2 \pm 1.5$ to $13.8 \pm 1.3 \mathrm{pg} / \mathrm{ml}$ after $180 \mathrm{~min}(P<0.005$, Fig. 1$)$.

Somatostatin responses to the eaten hamburger meal were measured in 16 normal subjects and 8 DU patients (Fig. 2). Mean plasma SLI increased significantly above basal concentrations in both groups, with mean SLI increases of $\sim 3 \mathrm{pg} / \mathrm{ml}$ in each. In contrast, mean plasma SLI in normal subjects did not increase when no meal was eaten. Peak SLI concentrations after either meal ranged from 9 to $26 \mathrm{pg} / \mathrm{ml}$ in normal subjects and from 11 to $25 \mathrm{pg} / \mathrm{ml}$ in DU patients. Although the mean integrated SLI response to the steak meal was larger than the integrated SLI response to the hamburger meal, the difference was not significant $(P>0.3)$.

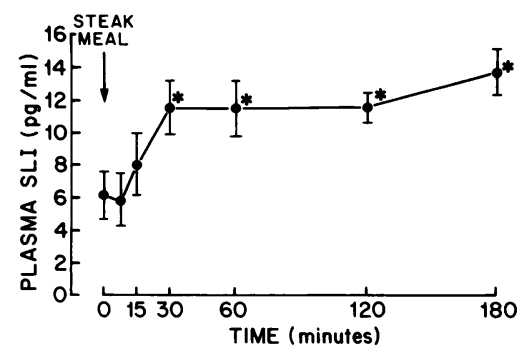

Figure 1. Effect of an ingested steak meal of mean $( \pm \mathrm{SE})$ plasma SLI concentrations in eight normal subjects (four men and four women). By $30 \mathrm{~min}$ after the meal and after, SLI concentrations were greater than basal in every subject $(*, P<0.05$ vs. basal concentration at 0 $\min )$. 


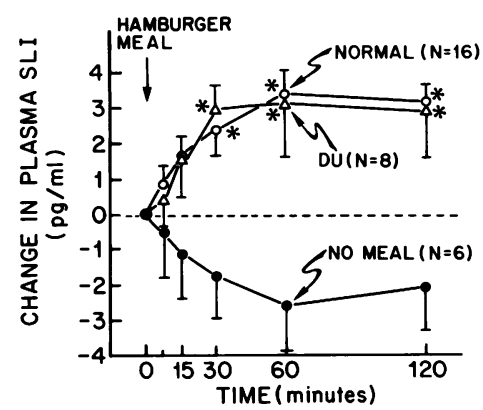

Figure 2. Mean basal-subtracted $( \pm \mathrm{SE})$ plasma SLI response to an eaten hamburger meal in 16 normal subjects and in 8 patients with chronic DU. No meal was given to six normal subjects as a control and mean SLI actually decreased with time $(P$ $<0.05$ ). Plasma SLI increased significantly and to approximately the same extent in both groups $(*, P<0.05$ vs. no meal control and also vs. basal concentration at $0 \mathrm{~min}$ ).

Effect of somatostatin on plasma SLI. As shown in Fig. 3, infusion of 5,10 , and $50 \mu \mathrm{g} / \mathrm{h} \mathrm{S}-14$ increased mean basal plasma SLI concentrations of nine healthy subjects in a dose-related manner. In other experiments, $\mathrm{S}-14$ or $\mathrm{NaCl}$ (control) was infused intravenously after a homogenized hamburger meal had been instilled in the stomach at $\mathrm{pH}$ 5.5. During the intravenous $\mathrm{NaCl}$ (control) infusion, plasma SLI increased $\sim 3 \mathrm{pg} / \mathrm{ml}(P<0.05)$ in response to the homogenized meal in both healthy subjects (Fig. 4, top) and DU patients (Fig. 4, bottom). During intravenous $\mathrm{S}-14$ infusion there was a dose-related increase in mean plasma SLI above $\mathrm{NaCl}$ control (Fig. 4), an increase that was linearly related to the microgram-per-hour dose of S-14 infused (SLI increase $=1.63$ dose $-0.9, r=0.996$ in healthy subjects; SLI increase $=1.90$ dose $-0.3, r=0.990$ in DU patients).

Infusion of $1,2.5,5$, and $10 \mu \mathrm{g} / \mathrm{h} \mathrm{S}-14$ produced mean SLI concentrations that were within the range seen after the eaten steak or hamburger meal $(\leq 26 \mathrm{pg} / \mathrm{ml})$, whereas 50 and 100 $\mu \mathrm{g} / \mathrm{h}$ caused mean SLI concentrations that were much higher than postprandial SLI concentrations (Figs. 3 and 4).

Effect of somatostatin on gastric acid secretion. As shown in Fig. 5 (top), $5 \mu \mathrm{g} / \mathrm{h}$ somatostatin had no significant effect on BAO in nine healthy subjects studied, whereas 10 and 50

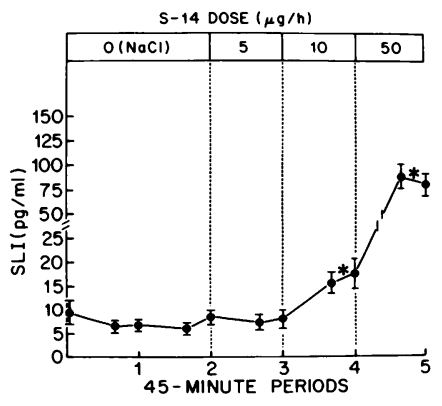

Figure 3. Effect of $0.15 \mathrm{M}$ $\mathrm{NaCl}$ (control) or 5,10 , and $50 \mu \mathrm{g} / \mathrm{h}$ synthetic human S-14 on mean $( \pm S E)$ plasma SLI concentrations in nine normal subjects (five men and four women). There was no significant change in mean plasma SLI from $\mathrm{NaCl}$ control during S-14 infusion at $5 \mu \mathrm{g} / \mathrm{h}$, whereas 10

and $50 \mu \mathrm{g} / \mathrm{h}$ led to significant $(*, P<0.05)$ increases in mean SLI concentrations. $10 \mu \mathrm{g} / \mathrm{h} \mathrm{S}-14$ led to mean SLI concentrations within the range of postprandial SLI concentrations, whereas $50 \mu \mathrm{g} / \mathrm{h} \mathrm{S}-14$ led to SLI concentrations above the postprandial range in every subject.
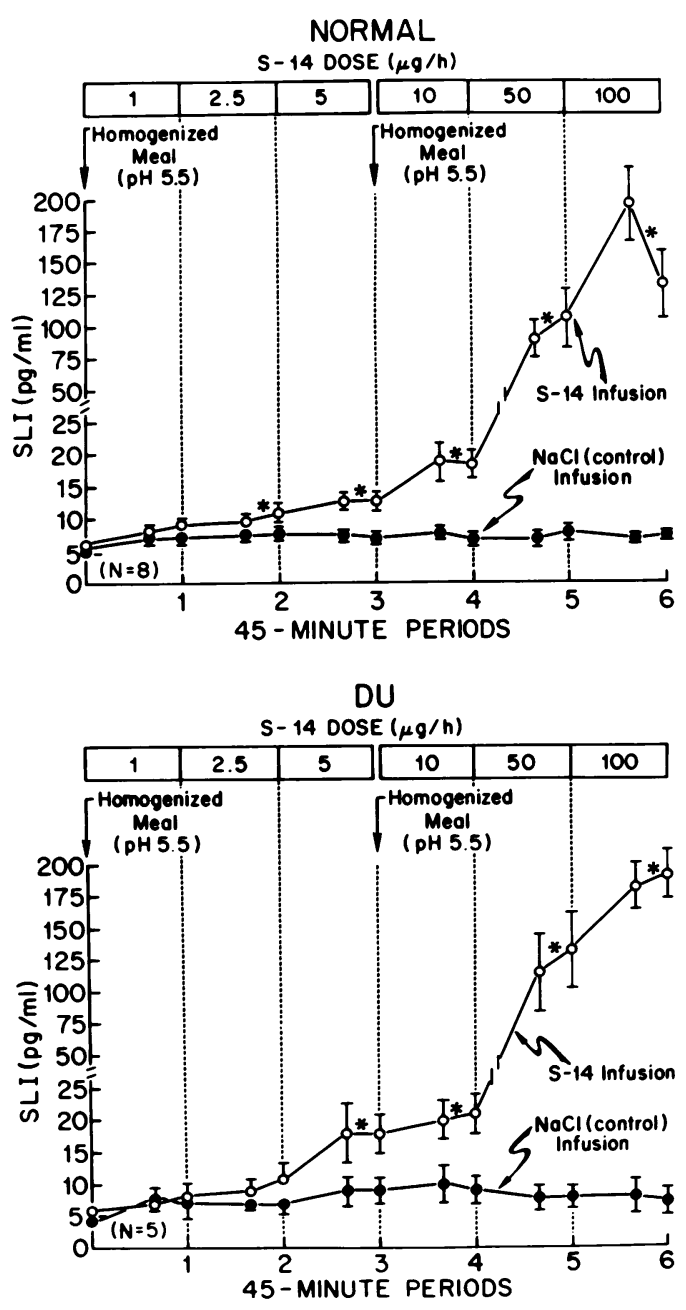

Figure 4. Effect of intravenous synthetic human S-14 or $0.15 \mathrm{M}$ $\mathrm{NaCl}$ (control) on mean $( \pm \mathrm{SE})$ plasma SLI concentrations after homogenized food at $\mathrm{pH} 5.5$ was infused into the stomachs of eight normal subjects (top) or five patients with DU (bottom). Two identical "meals" were infused so that six doses of S-14 could be tested (see straight arrows). Mean plasma SLI during S-14 infusion increased above $\mathrm{NaCl}$ control in a dose-related manner $(*, P<0.05$ vs. $\mathrm{NaCl}$ control). S-14 doses of $\leq 10 \mu \mathrm{g} / \mathrm{h}$ produced mean SLI concentrations within the range observed after an eaten steak or hamburger meal, whereas S-14 doses of 50 and $100 \mu \mathrm{g} / \mathrm{h}$ produced much higher mean SLI concentrations.

$\mu \mathrm{g} / \mathrm{h} \mathrm{S}-14$ inhibited acid output by $48 \%(P<0.02)$ and $83 \%(P$ $<0.005$ ), respectively. Both 10 and $50 \mu \mathrm{g} / \mathrm{h} \mathrm{S}-14$ reduced gastric volume output significantly, whereas only $50 \mu \mathrm{g} / \mathrm{h} \mathrm{S}-14$ significantly reduced the hydrogen ion concentration of gastric juice (Table I).

Food-stimulated acid secretion during the $\mathrm{NaCl}$ (control) infusion was lower in normal subjects than in DU patients $(16.8 \pm 3.6$ vs. $24.8 \pm 8.2 \mathrm{mmol} / \mathrm{h}, P<0.05)$. As shown in Fig. 6 , significant inhibition of food-stimulated gastric acid secretion 

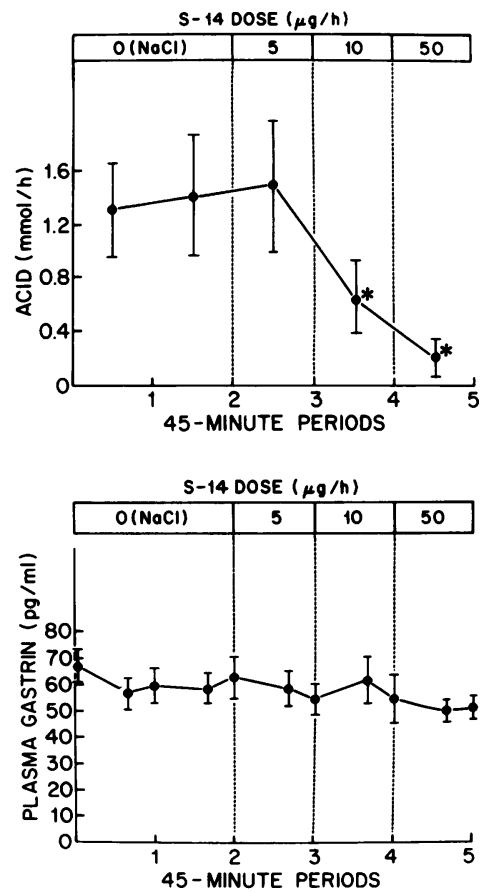

Figure 5. Effect of intravenous $\mathrm{S}-14$ on mean $( \pm \mathrm{SE})$ basal acid output (top) and on mean $( \pm \mathrm{SE})$ basal plasma gastrin concentrations (bottom) in nine normal subjects. Significant $(P$ $<0.05$ ) inhibition of acid output by somatostatin is indicated by asterisks. Peak acid output to $6 \mu \mathrm{g} / \mathrm{kg}$ subcutaneous pentagastrin averaged $29.2 \pm 3.0 \mathrm{mmol} / \mathrm{h}$ in these nine subjects.

occurred with S-14 doses $\geq 10 \mu \mathrm{g} / \mathrm{h}$ in healthy subjects (top) and $\geq 5 \mu \mathrm{g} / \mathrm{h}$ in DU patients (bottom).

Effect of somatostatin on plasma gastrin. As indicated in Fig. 5 (bottom), neither 5 nor $10 \mu \mathrm{g} / \mathrm{h} \mathrm{S}-14$ significantly affected basal plasma gastrin concentrations in the nine healthy subjects studied. $50 \mu \mathrm{g} / \mathrm{h} \mathrm{S}-14$ reduced mean plasma gastrin concentrations by $16 \%(P=0.05)$.

Before homogenized food, basal plasma gastrin concentrations averaged $49 \pm 6 \mathrm{pg} / \mathrm{ml}$ in eight normal subjects, and $93 \pm 9$ $\mathrm{pg} / \mathrm{ml}$ in $5 \mathrm{DU}$ patients $(P<0.05)$. Basal-subtracted mean plasma gastrin responses to homogenized food during the $\mathrm{NaCl}$ (control) infusion were similar in normal subjects and DU patients $(86 \pm 23$ vs. $95 \pm 19 \mathrm{pg} / \mathrm{ml}$, respectively, $P>0.05)$. In both groups, only 50 and $100 \mu \mathrm{g} / \mathrm{h} \mathrm{S}-14$ significantly reduced gastrin responses to food (Fig. 7).

Table I. Effect of S-14 on Mean ( \pm SEM) Basal Gastric Volume Output and Basal $\mathrm{H}^{+}$Concentration in Nine Subjects

\begin{tabular}{lll}
\hline S-14 dose & Volume output & $\mathrm{H}^{+}$concentration \\
\hline$\mu g / h$ & $m l / 45 \mathrm{~min}$ & mmol/liter \\
$0(\mathrm{NaCl})^{*}$ & $29.0+3.7$ & $32.3 \pm 6.7$ \\
5 & $22.7 \pm 3.8$ & $37.7 \pm 8.2$ \\
10 & $19.0 \pm 1.9 \ddagger$ & $23.4 \pm 7.4$ \\
50 & $16.2 \pm 3.2 \ddagger$ & $6.4 \pm 3.6 \ddagger$ \\
\hline
\end{tabular}

* Average of two 45-min control periods.

$¥ P<0.05$ vs. $\mathrm{NaCl}$ control.
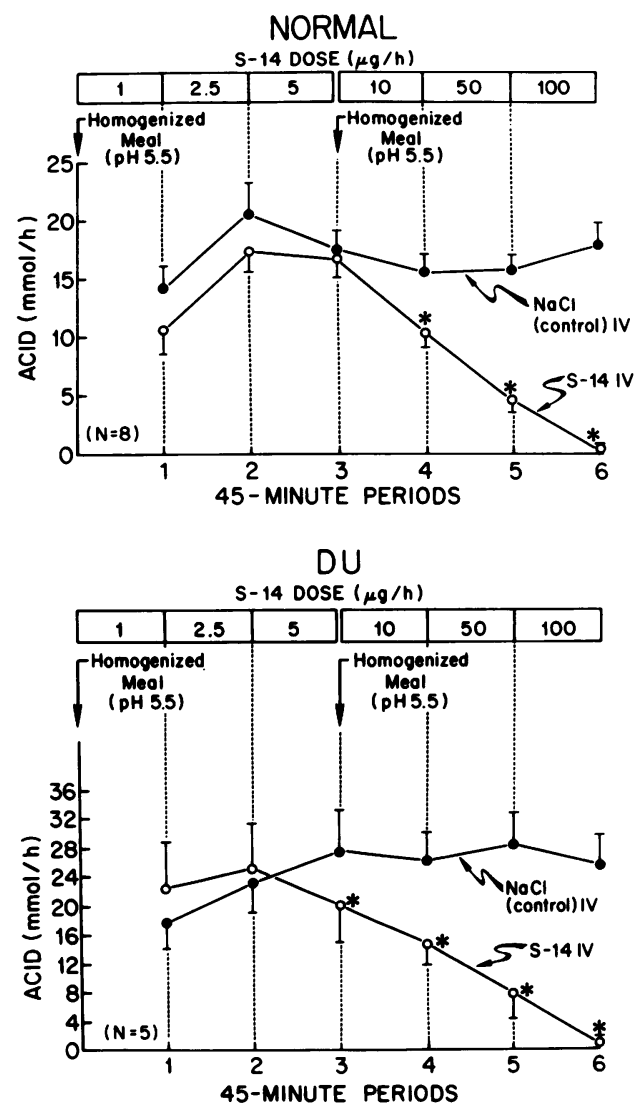

Figure 6. Effect of intravenous S-14 or $0.15 \mathrm{M} \mathrm{NaCl}$ (control) on mean ( \pm SE) food-stimulated acid secretion in eight normal subjects (top) and in five patients with chronic DU (bottom). Significant inhibition of acid secretion by somatostatin is indicated by asterisks ( $P$ $<0.05$ )

Fig. 8 compares percent inhibition of food-stimulated gastric acid secretion and food-stimulated plasma gastrin responses as a function of plasma SLI in DU patients and normal subjects. DU patients were no more or less sensitive than normal to the inhibitory effects of circulating somatostatin on acid secretion or gastrin release.

Effect of somatostatin on plasma insulin and glucagon. While $5 \mu \mathrm{g} / \mathrm{h} \mathrm{S}-14$ had no significant effect, 10 and $50 \mu \mathrm{g} / \mathrm{h} \mathrm{S}-14$ significantly reduced basal plasma insulin and glucagon concentrations in nine healthy subjects studied (Fig. 9). Although not shown in Fig. 9, mean plasma glucose concentrations remained nearly constant at $74 \pm 2 \mathrm{mg} / \mathrm{dl}$ during S-14 infusion.

As shown in Fig. 10, plasma insulin and glucagon responses to homogenized food were inhibited by doses of S-14 $\geq 5$ $\mu \mathrm{g} / \mathrm{h} .50$ and $100 \mu \mathrm{g} / \mathrm{h} \mathrm{S}-14$ completely inhibited insulin and glucagon release.

\section{Discussion}

Our finding that plasma SLI concentrations increased signifcantly above basal concentrations after a meal agrees with pre- 
NORMAL

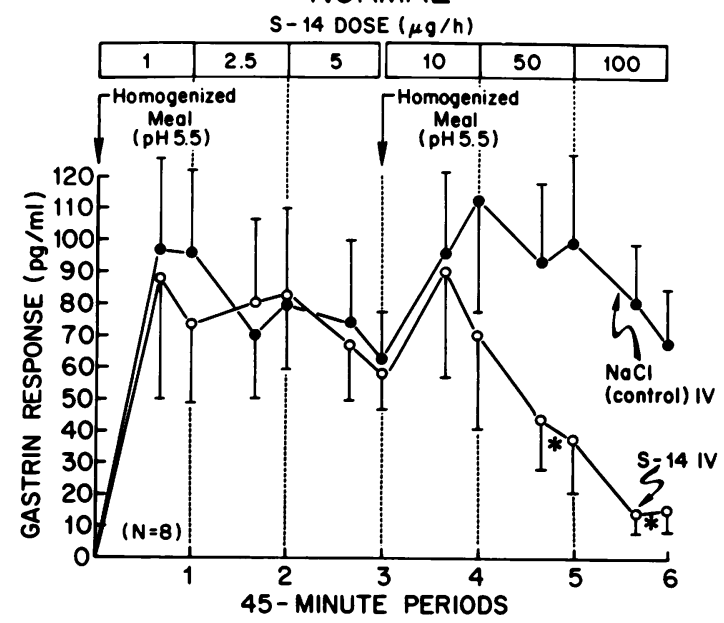

DU

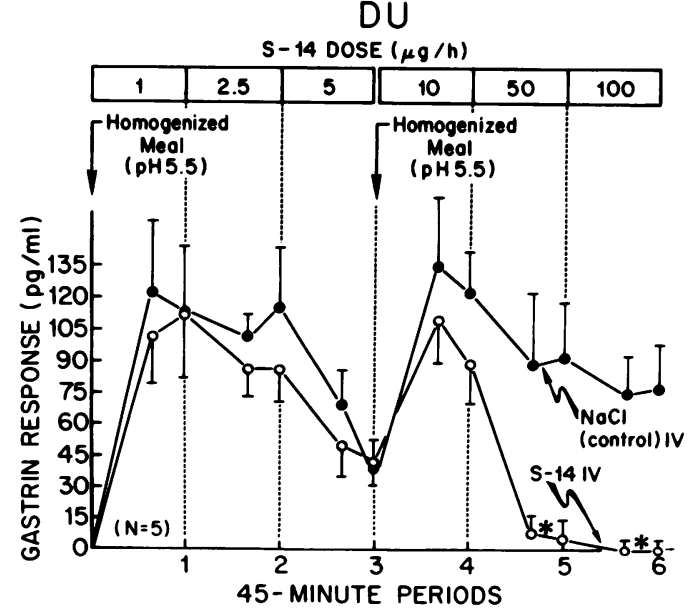

Figure 7. Effect of intravenous S-14 or $0.15 \mathrm{M} \mathrm{NaCl}$ (control) on mean $( \pm \mathrm{SE})$ basal-subtracted plasma gastrin responses to homogenized food at pH 5.5 in eight normal healthy subjects (top) and five patients with chronic DU (bottom). Significant reductions in plasma gastrin concentrations by somatostatin are shown by asterisks $(P$ $<0.05$ ). Basal plasma gastrin averaged $49 \pm 6 \mathrm{pg} / \mathrm{ml}$ in normal subjects and $93 \pm 9 \mathrm{pg} / \mathrm{ml}$ in DU patients $(P<0.05)$.

vious reports (3-8), although our results differ quantitatively from some of these reports. In our study, basal SLI concentrations averaged $7-9 \mathrm{pg} / \mathrm{ml}$ in healthy subjects and DU patients, whereas others have reported mean basal SLI concentrations as low as $9 \mathrm{pg} / \mathrm{ml}$ (3) or as high as $174 \mathrm{pg} / \mathrm{ml}$ (4). Moreover, our finding that plasma SLI increased up to $8 \mathrm{pg} / \mathrm{ml}$ in response to a steak meal compares with reported postprandial SLI increases as low as $6 \mathrm{pg} / \mathrm{ml}$ (3) or as high as $130 \mathrm{pg} / \mathrm{ml}(4)$. The reason for these quantitative differences is uncertain, but it is possible that our preliminary plasma extraction step using octadecylsilyl silica cartridges (16) results in lower SLI concentrations by reducing nonspecific interference with the assay by plasma proteins.

\section{ACID SECRETION}

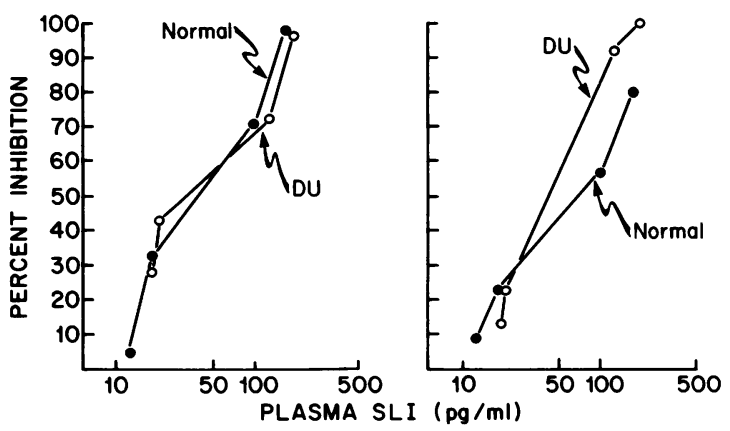

Figure 8. Relationship between mean plasma SLI concentrations during intravenous S-14 infusion and mean percent inhibition of foodstimulated gastric acid secretion or plasma gastrin concentration in eight normal subjects and five DU patients. Only data for somatostatin doses of $5,10,50$, and $100 \mu \mathrm{g} / \mathrm{h}$ are shown and plasma SLI is expressed on a logarithmic scale. Compared with normal subjects, DU patients were no more or less sensitive to inhibitory effects of circulating somatostatin on acid secretion or gastrin release.

Antibody $80 \mathrm{C}$, which we use to measure SLI in plasma, has only detected S-14 and has never detected a large molecular weight form of somatostatin corresponding to S-28 in canine or human plasma (Unger, R. H., unpublished data). Thus, it is likely that the $8 \mathrm{pg} / \mathrm{ml}$ increase in plasma SLI after the steak meal represented only S-14 somatostatin and not another species of somatostatin. Some groups using different antibodies have reported increases in S-28 in plasma after meals $(6,8)$, whereas our group was unable to detect S-28 in canine plasma using antibody R101 obtained from Arimura (23). It is possible that the magnitude of the total somatostatin response to a meal (S-14 plus S-28) may be even greater than estimated by antibody $80 \mathrm{C}$ in the present study.

We were interested in determining whether the increment in plasma SLI after a steak meal is of sufficient magnitude to affect potential target tissues in the stomach and endocrine pan-

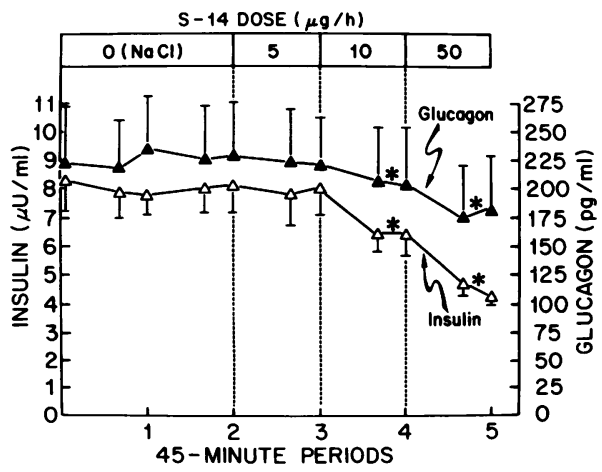

Figure 9. Effect of intravenous S-14 on mean ( \pm SE) basal plasma insulin and glucagon concentrations in nine normal subjects. Signifcant $(P<0.05)$ reductions in plasma hormone concentrations below $\mathrm{NaCl}$ control are shown as asterisks. 


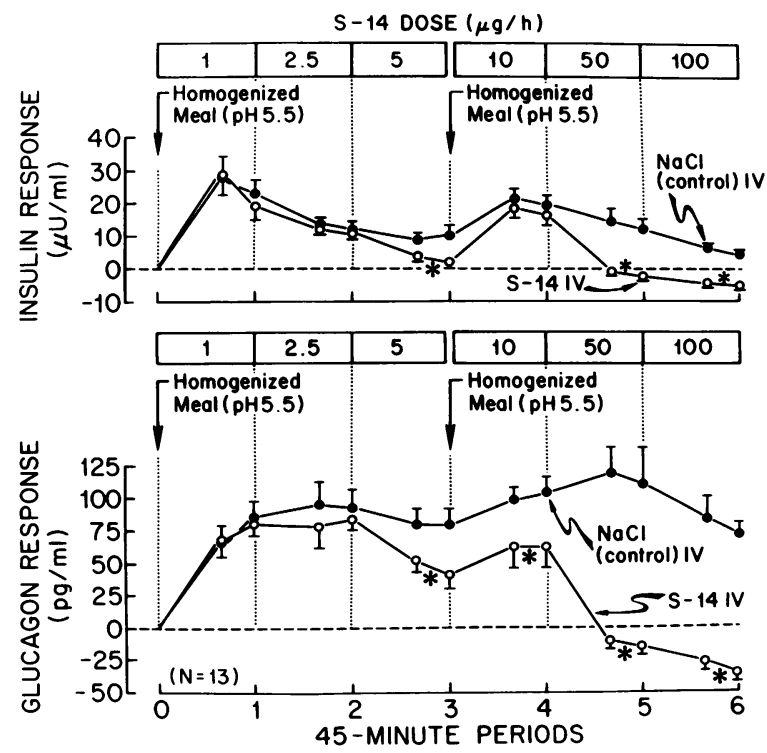

Figure 10. Effect of intravenous S-14 on mean $( \pm \mathrm{SE})$ plasma insulin response (upper) and plasma glucagon response (lower) to homogenized food in 13 subjects (8 normal and 5 with duodenal ulcer). Results were similar in normal subjects and ulcer patients and therefore data were combined. Significant $(P<0.05)$ reductions in plasma hormone concentrations below $\mathrm{NaCl}$ control are shown by asterisks.

creas. An intravenous infusion of $10 \mu \mathrm{g} / \mathrm{h}$ of synthetic S-14 led to mean plasma SLI concentrations within the range of those that occur after a steak meal and significantly reduced basal gastric acid output and basal plasma insulin and glucagon concentrations. Moreover, food-stimulated acid secretion, insulin release, and glucagon release were inhibited significantly at mean SLI concentrations within the range seen after ingested steak or hamburger meals $(10-20 \mathrm{pg} / \mathrm{ml}$ or $\sim 10 \mathrm{pM})$. Our plasma insulin and glucagon data agree closely with a recent report in which $73 \mathrm{pmol} / \mathrm{kg} \cdot \mathrm{h} \mathrm{S}-14$ (or $\sim 8 \mu \mathrm{g} / \mathrm{h}$ ) was used to simulate the postprandial SLI increase (7). The effect of such small amounts of somatostatin on gastric acid secretion has not been reported previously. The finding that gastric acid secretion was inhibited at relatively low concentrations of circulating somatostatin suggests that the parietal cell (or a cell that stimulates the parietal cell) may be a major target for somatostatin in man.

The exact mechanism by which somatostatin inhibited gastric acid secretion is uncertain. Somatostatin reduced gastric volume output significantly, making it unlikely that somatostatin reduced acid output by stimulating alkaline secretion. Gastric acid secretion rates were reduced by S-14 doses and at plasma SLI concentrations that had no effect on plasma gastrin concentrations. Therefore, this study and others $(9-12,24)$ suggest that somatostatin inhibits gastric acid secretion by a mechanism independent of the hormone gastrin. Somatostatin inhibits acetylcholine release from guinea pig ileum in vitro (25), although it is unknown if this would occur in the stomach in vivo. In rats, the inhibitory effect of somatostatin on acid secretion was prevented by indomethacin pretreatment, which suggests that somatostatin may act indirectly via endogenous prostaglandins (26). However, the inhibitory effect of somatostatin on foodstimulated acid secretion is not blocked by indomethacin pretreatment in humans (Colturi T. J., and M. Feldman; unpublished data). Efforts to demonstrate by in vitro studies a direct inhibitory effect of somatostatin on isolated parietal cells have yielded conflicting results $(27,28)$.

Whether the rise in plasma somatostatin reflects true hormonal secretion or an overflow of somatostatin released primarily into the interstitium to act on local target cells is uncertain. True hormonal action is strongly supported by the demonstration that exogenous somatostatin perfused into the isolated dog pancreas effectively inhibits insulin and glucagon release at concentrations that are only $10-20 \%$ of the concentration of endogenous somatostatin in the venous effluent (29). This high sensitivity to very small changes in arterial somatostatin concentration suggests that somatostatin receptors in the endocrine pancreas are located in a somatostatin-poor compartment that is separated from the venous compartment into which somatostatin is secreted at high concentrations. While this does not necessarily exclude the existence of a paracrine compartment, it makes it less likely on both anatomical and functional grounds. The findings of the present study are consistent with this conclusion for the endocrine pancreas and suggest that it might apply also to the gastric mucosa.

Two groups have reported lower than normal SLI in antral mucosa of patients with DU $(14,15)$. Because exogenous somatostatin can suppress acid secretion and gastrin release (9-12), the possibility that a relative deficiency of somatostatin could contribute to acid hypersecretion and hypergastrinemia in DU patients was considered in the present study. We found similar basal SLI concentrations in DU patients and normal subjects, even though DU patients had significantly higher rates of basal acid secretion and significantly higher basal plasma gastrin concentrations. Moreover, despite higher food-stimulated acid secretion in DU patients, plasma SLI responses to the hamburger were nearly identical in DU patients and normal subjects, whether the hamburger was eaten or homogenized and infused directly into the stomach at pH 5.5. Our finding that the SLI response to the hamburger was nearly identical whether the meal was eaten or infused directly into the stomach at $\mathrm{pH}$ 5.5 suggests that cephalic stimulation and intragastric $\mathrm{pH}$ play relatively unimportant roles in the SLI response to food in man.

Our data tend to exclude the possibility that DU patients may be less sensitive to inhibitory effects of somatostatin on gastric secretion. Food-stimulated gastric acid secretion and foodstimulated plasma gastrin concentrations were reduced to similar degrees by similar circulating levels of somatostatin in DU patients and normal subjects (Fig. 8). Although we cannot exclude the existence of a subset of DU patients in whom somatostatinrelated abnormalities play a pathogenetic role, our experiments provide no support for this possibility. 


\section{Acknowledgments}

The authors wish to thank Virginia Harris, Kay McCorkle, Tina Barnett, Julie Oliver-Touchstone, Mary Walker, Peter Chew, and June Ferrari for expert technical assistance; Dr. John $\mathrm{H}$. Walsh at the Center for Ulcer Research and Education in Los Angeles for measuring plasma gastrin; and Vicky Slagle and Brenda Jones for preparing the manuscript.

This work was supported in part by grants AM16816, AM17328, and AM-02700 from the National Institute of Arthritis, Metabolism and Digestive Diseases and by the Veterans Administration. Dr. Colturi was supported by a National Institutes of Health Training Grant (T32AM07100).

\section{References}

1. Walsh, J. H. 1983. Gastrointestinal peptide hormones. In Gastrointestinal Disease. M. H. Sleisenger and J. S. Fordtran, editors. W. B. Saunders Co., Philadelphia. Third ed. 1983:54-96.

2. Larsson, L.-I., N. Goltermann, L. de Magistris, J. F. Rehfeld, and T. W. Schwartz. 1979. Somatostatin cell processes in pathways for paracrine secretion. Science (Wash. DC). 205:1393-1395.

3. Tsuda, K., H. Sakurai, Y. Seino, S. Seino, K. Tanigawa, H. Kuzuya, and H. Imura. 1981. Somatostatin-like immunoreactivity in human peripheral plasma measured by radioimmunoassay following affinity chromatography. Diabetes. 30:471-474.

4. Vinik, A. I., N. S. Levitt, B. L. Pimstone, and L. Wagner. 1981. Peripheral plasma somatostatin-like immunoreactive responses to insulin hypoglycemia and a mixed meal in healthy subjects and in noninsulindependent maturity-onset diabetics. J. Clin. Endocrinol. Metab. 52:330 337.

5. Wass, J. A. H., E. Penman, J. R. Dryburgh, D. Tsiolakis, P. L. Goldberg, A. M. Dawson, G. M. Besser, and L. H. Rees. 1980. Circulating somatostatin after food and glucose in man. Clin. Endocrinol. 12:569574.

6. Penman, E., J. A. H. Wass, S. Medbak, L. Morgan, J. M. Lewis, G. M. Besser, and L. H. Rees. 1981. Response to circulating immunoreactive somatostatin to nutritional stimuli in normal subjects. Gastroenterology. 81:692-699.

7. Souquet, J. C., R. Rambliere, J. P. Riou, M. Beylot, R. Cohen, R. Mornex, and J. A. Chayvialle. 1983. Hormonal and metabolic effects of near physiological increase in plasma immunoreactive somatostatin 14. J. Clin. Endocrinol. Metab. 56:1076-1079.

8. Polonsky, K. S., S. E. Shoelson, and H. M. Docherty. 1983. Plasma somatostatin 28 increases in response to feeding in man. J. Clin. Invest. 71:1514-1518.

9. Bloom, S. R., C. H. Mortimer, M. O. Thorner, G. M. Besser, R. Hall, A. Gomez-Pan, V. M. Roy, R. O. G. Russel, D. H. Coy, A. J. Kastin, and A. V. Schally. 1974. Inhibition of gastrin and gastric-acid secretion by growth-hormone release-inhibiting hormone. Lancet. II:1106-1109.

10. Vatn, M. H., E. Schrumpf, K. F. Hanssen, and J. Myren. 1977. The effect of somatostatin on pentagastrin-stimulated gastric secretion and on plasma gastrin in man. Scand. J. Gastroenterol. 12:833-839.

11. Konturek, S. J., J. Swierczek, N. Kwiecien, E. Mikos, J. Oleksy, and Z. Wierzbicki. 1977. Effect of somatostatin on meal-induced gastric secretion in duodenal ulcer patients. Dig. Dis. 22:981-988.

12. Phillip, J., S. Domschke, W. Domschke, H.-J. Urbach, M. Reiss, and L. Demling. 1977. Inhibition by somatostatin of gastrin release and gastric acid responses to meals and to pentagastrin in man. Scand. $J$. Gastroenterol. 12:261-265.

13. Soll, A. H., and J. I. Isenberg. 1983. Duodenal ulcer diseases. In Gastrointestinal Disease. M. H. Sleisenger and J. S. Fordtran, editors. W. B. Saunders Co., Philadelphia. Third ed. 40:625-672.

14. Chayvialle, J. A. P., F. Descos, C. Bernard, A. Martin, C. Barbe, and C. Partensky. 1978. Somatostatin in mucosa of stomach and duodenum in gastroduodenal disease. Gastroenterology. 75:13-19.

15. Sumii, K., T. Fukushima, K. Hirata, Y. Matsumoto, E. Sanuki, S. Tsumaru, M. Sumioka, A. Miyoshi, and Y. Miyachi. 1981. Antral gastrin and somatostatin concentrations in peptic ulcer patients. Peptides. 2(Suppl. 2):281-283.

16. Vasquez, B., V. Harris, and R. H. Unger, 1982. Extraction of somatostatin from human plasma on octadecylsilyl silica. J. Clin. Endocrinol. Metab. 55:807-809.

17. Feldman, M. Gastric secretion. In Gastrointestinal Disease. M. H. Sleisenger and J. S. Fordtran, editors. W. B. Saunders Co., Philadelphia. 1983:541-558.

18. Moore, E. W., and R. W. Scarlata. 1965. The determination of gastric acidity by the glass electrode. Gastroenterology. 49:178-188.

19. Fordtran, J. S., and J. H. Walsh. 1973. Gastric acid secretion rate and buffer content of the stomach after eating. Results in normal subjects and in patients with duodenal ulcer. J. Clin. Invest. 52:645657.

20. Walsh, J. H. 1974. Radioimmunoassay of gastrin. In Nuclear Medicine in Vitro. B. Rothfield, editor. J. B. Lippincott, Philadelphia. 231-248.

21. Yalow, R. S., and S. A. Berson. 1960. Immunoassay of endogenous plasma insulin in man. J. Clin. Invest. 39:1157-1175.

22. Faloona, G. R., and R. H. Unger. 1974. Glucagon. In Methods in Hormone Radioimmunoassay. B. M. Jaffe and H. R. Behrmann, editors. Academic Press, Inc., New York. 317-330.

23. Schusdziarra, V., E. Zyznar, D. Rouiller, V. Harris, and R. H. Unger. 1980. Free somatostatin in the circulation. Amounts and molecular sizes of somatostatin-like immunoreactivity in portal, aortic, and vena caval plasma of fasting and meal-stimulated dogs. Endocrinology. 107:1572-1576.

24. Seal, A., T. Yamada, H. Debas, J. Hollinshead, B. Osadchey, G. Aponte, and J. Walsh. 1982. Somatostatin-14 and -28; clearance and potency on gastric function in dogs. Am. J. Physiol. 243:G97-G102.

25. Guillemin, R. 1983. Somatostatin inhibits the release of acetylcholine induced electrically in the myenteric plexus. Endocrinology. 99:1653-1654.

26. Ligumsky, M., Y. Goto, H. Debas, and T. Yamada. 1983. Prostaglandins mediate inhibition of gastric acid secretion by somatostatin in the rat. Science (Wash. DC). 219:301-303.

27. Perez-Reyes, E., N. A. Payne, and J. G. Gerber. 1983. Effect of somatostatin, secretin, and glucagon on secretagogue stimulated aminopyrine uptake in isolated canine parietal cells. Agents Actions. 13:265268.

28. Chew, C. S. 1983. Inhibitory action of somatostatin on isolated gastric glands and parietal cells. Am. J. Physiol. 245:G221-G229.

29. Kawai, K., E. Ipp, L. Orci, A. Perrelet, and R. H. Unger. 1982. Circulating somatostatin acts on the islets of Langerhans by way of a somatostatin-poor compartment. Science (Wash. DC). 218:477-478. 